\title{
The Grassland vegetation of Platberg, eastern Free State, South Africa
}

\author{
Authors: \\ Robert F. Brand \\ Leslie R. Brown ${ }^{1}$ \\ Pieter J. du Preez ${ }^{2}$ \\ Affiliations: \\ ${ }^{1}$ Applied Behavioural Ecology \\ and Ecosystem Research \\ Unit, University of South \\ Africa, South Africa \\ ${ }^{2}$ Department of Plant \\ Sciences, University of the \\ Free State, South Africa \\ Correspondence to: \\ Leslie Brown \\ Email: \\ Irbrown@unisa.ac.za \\ Postal address: \\ Private bag X6, Florida 1710 \\ South Africa \\ Dates: \\ Received: 28 Sept. 2010 \\ Accecpted: 07 Sept. 2011 \\ Published: 10 Nov. 2011 \\ How to cite this article: \\ Brand, R.F., Brown, L.R. \& \\ Du Preez, P.J., 2011, 'The \\ Grassland vegetation of \\ Platberg, eastern Free State, \\ South Africa', Koedoe 53(1), \\ Art. \#1027, 13 pages. http:// \\ dx.doi.org/10.4102/koedoe. \\ v53i1.1027
}

C 2011. The Authors. Licensee: AOSIS OpenJournals. This work is licensed under the Creative Commons Attribution License.
Platberg is an inselberg that presents a refuge for indigenous plants and animals. Uncontrolled human access to this area threatens this sensitive ecosystem. The vegetation of Platberg was investigated to obtain an inventory of the different plant species and communities present in this area. A hierarchical classification, a description and an ecological interpretation of the grassland communities of Platberg are presented. A total of 169 sample plots were placed on a stratified random basis within the study area. From a TWINSPAN classification a total of 27 different plant communities, which can be grouped into two major community types, nine communities, 18 sub-communities and six variants, were identified. A significant difference in species richness was found between the two major communities, with the higher-altitude communities having a higher species richness than the communities on the lower-lying slopes. A total of 26 endemic or near endemic Drakensberg Alpine Centre species were recorded.

Conservation implications: Anthropogenic influences are felt globally on ecosystems. Highaltitude habitats and organisms will be affected first. Inselbergs have high levels of endemic organisms and are reservoirs and refugia for unique genetic material. This grassland plant community survey of Platberg provides valuable information on inselberg ecology for conservation planning.

\section{Introduction}

The Grassland Biome of southern Africa is continually under threat from anthropoidal activities such as crop production, overgrazing, residential and industrial development, and invasion by alien plant species. These pressures threaten the biodiversity of this sensitive biome (Van Wyk \& Smith 2001). The prevention of large-scale loss of biodiversity is a daunting challenge facing conservationists worldwide (ed. Huntley 1994). In order to conserve our natural resources it is important that ecosystems are studied to compile an inventory of the different plant and animal species present.

Platberg (near Harrismith in the eastern Free State) is an inselberg located within the Grassland Biome. The vegetation comprises a mosaic of woody and grass-dominated vegetation units with short to tall sour grasses constituting the majority of the species composition (Mucina \& Rutherford 2006). The Korannaberg near Excelsior (also in the eastern Free State) is the only other inselberg where a phytosociological study was performed, by Du Preez (1991, 1992), Du Preez and Bredenkamp (1991) and Du Preez, Bredenkamp and Venter (1991). Studies of the grassland vegetation of inselbergs in Africa are limited to studies in west Africa by Porembski and Barthlott (1995), Porembski and Brown (1995), Porembski et al. (1996) and Porembski et al. (1998), in central Atlantic Africa by Parmentier et al. (2006), and in Namibia by Burke $(2001,2004)$. The lack of data of inselberg vegetation can be attributed to the physical difficulty of accessing inselbergs. This inaccessibility also contributes to the unique biodiversity found on these high-altitude areas (Van Wyk \& Smith 2001).

Owing to the proposed commercial development on and around Platberg, as well as the aims of the Maloti Drakensberg Transfrontier Project, it was considered necessary to undertake a more detailed plant ecology survey to describe and classify the vegetation of Platberg. This paper aims to classify and describe the grassland vegetation present on the Platberg plateau and slopes.

\section{Study area}

Platberg $\left(29^{\circ} 10^{\prime} \mathrm{S}, 28^{\circ} 16^{\prime} \mathrm{E}\right)$ is located along the N3 highway between Johannesburg and Durban. It forms a distinctive flat-topped, L-shaped plateau with clear-cut contact between the dolerite plateau and the Cave Sandstone of the Clarens formation (Figure 1). The soil is generally shallow and weakly developed lithosols, with plains soil being mostly sandy loam containing boulders and gravel (Hoare \& Bredenkamp 2001; Mucina \& Rutherford 2006). 


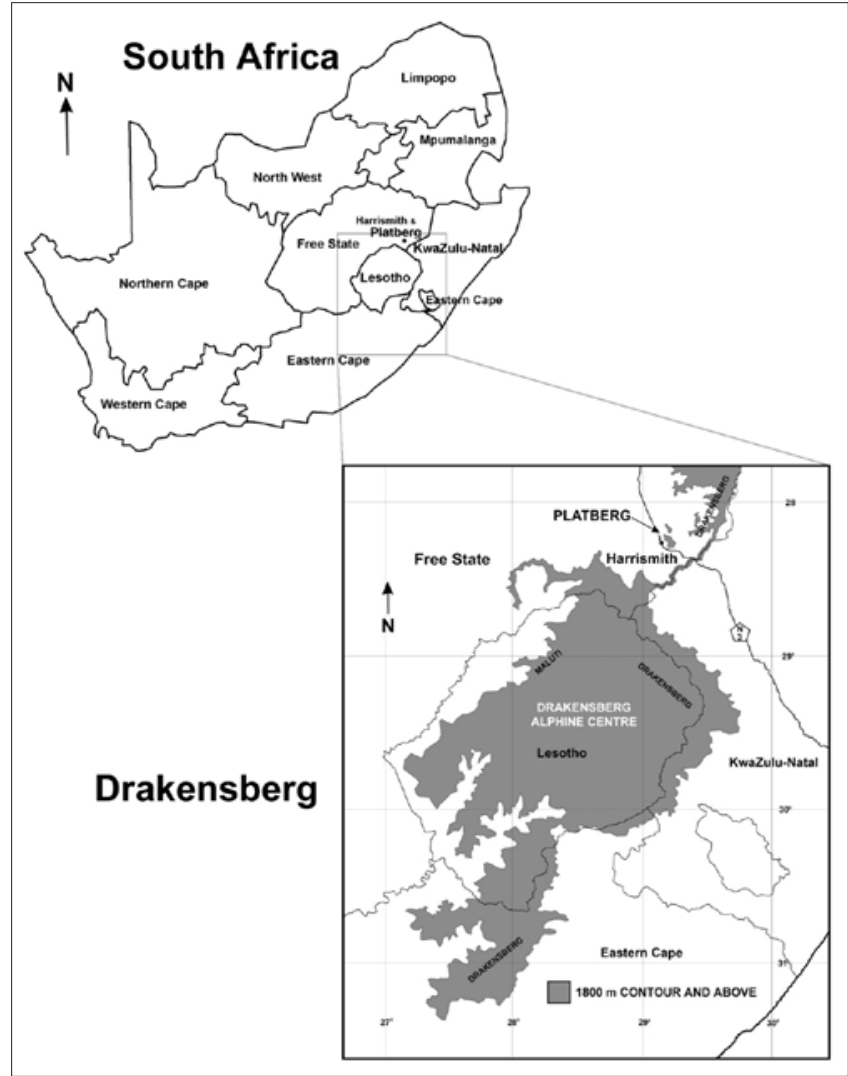

FIGURE 1: Location of the study area.

Altitudes range from 1900 m.a.s.l. to 2394 m.a.s.l. with a surface area of approximately 3000 ha for the study site. The slopes are steep, with numerous vegetated gullies and boulder scree slopes below the vertical cliffs. A permanent stream drains off the southern side and flows off the escarpment in a steeply incised gully (Figure 2).

Rainfall is seasonally, with the most rain falling between November and March. Mean annual precipitation for the Drakensberg is $739 \mathrm{~mm}$, with Platberg's eastern summit receiving up to $1200 \mathrm{~mm}$ (SA Weather Services 2007). The area has a cold temperature regime (June and July being the coldest months), with a mean annual temperature of $9.6^{\circ} \mathrm{C}$. Minimum and maximum temperatures range from $-2{ }^{\circ} \mathrm{C}$ (July) to $24{ }^{\circ} \mathrm{C}$ (January), respectively.

\section{Materials and methods}

The scope of the study was to sample above the 1800-m contour in order to work within the limits set by Killick (1963, 1978), who regarded the region in the Drakensberg above $1800 \mathrm{~m}$ as a distinct floristic region called the Afro-Alpine Region.

Plot sizes were fixed at $16 \mathrm{~m}^{2}$ (Du Preez \& Bredenkamp 1991; Malan 1998). After a recognisance of the study area, a total of 169 sample plots were placed on a stratified-random basis within representative stands of vegetation to exclude as much heterogeneity as possible with regard to floristic composition, structure and habitat. The general position of the sample plots was pre-determined according to aerial photographs but each section within the identified stand had the same chance of being selected. Chosen sample plots found not to be representative of the general vegetation were moved to be more representative, in accordance with the requirements for Braun-Blanquet surveys (Mueller-Dombois \& Ellenberg 1974; Westhoff \& Van der Maarel 1980).

All species present in sample plots, except bryophytes and lichens, were recorded. Taxon names conform to those of Germishuizen and Meyer (2003). Over 1500 floristic collections were made and identified at either the Geo-Potts Herbarium (University of the Free State, Bloemfontein) or the National Herbarium in Pretoria. The specimens are currently housed at the Geo-Potts Herbarium at the University of the Free State. The cover or abundance of each species was estimated using the modified 9-degree Braun-Blanquet sampling scale (Keddy 2007; Kent \& Coker 1992). The surveys were conducted over a period of 24 months (February 2005 to January 2007).

Environmental data collected included geology (Johnson et al. 2006), soil type (Soil Classification Working Group 1991), aspect, exposure, size of rocks, altitude, percentage of the area covered by rock, and topography. Erosion and slope were estimated as described by Brand, Du Preez and Brown (2008). Additional notes were made on management and utilisation of the area.

Floristic data were captured on the floristic database TURBOVEG (Hennekens 1996a, 1998). The data were then exported to MEGATAB (Hennekens 1996b), followed by the use of TWINSPAN (a multivariate classification technique) to classify the different plant communities. Further refinement was achieved by the repositioning of species and relevés. Plant communities were recognised by using diagnostic and/or characteristic species as defined by Westhoff and Van der Maarel (1980) and Kent and Coker (1992). Species were considered to be diagnostic if they were present in at least $40 \%$ of the relevés of a specific plant community, with a constancy of $20 \%$ or less in other communities. In exceptional cases, species with a constancy of between $30 \%$ and $40 \%$ were included if they had a constancy of less than $5 \%$ in other communities. The results are presented in a phytosociological table (see online supplement). In order to compare the mean species abundance of the two major communities, a parametric $t$-test for homogeneous variances was used as the community species variances were not significantly different $(F=1.111, p>0.05)$. The nonparametric Kruskal-Wallis analysis of variance (ANOVA) by ranks was used to compare species abundance within major communities. Data were analysed using Statistica version 9.0 (STATISTICA 2009).

\section{Results}

\section{Vegetation classification and description}

The hierarchical classification compiled from 169 relevés resulted in the identification of 27 different plant communities that can be grouped into two major community types, nine communities, eighteen sub-communities and six variants, 


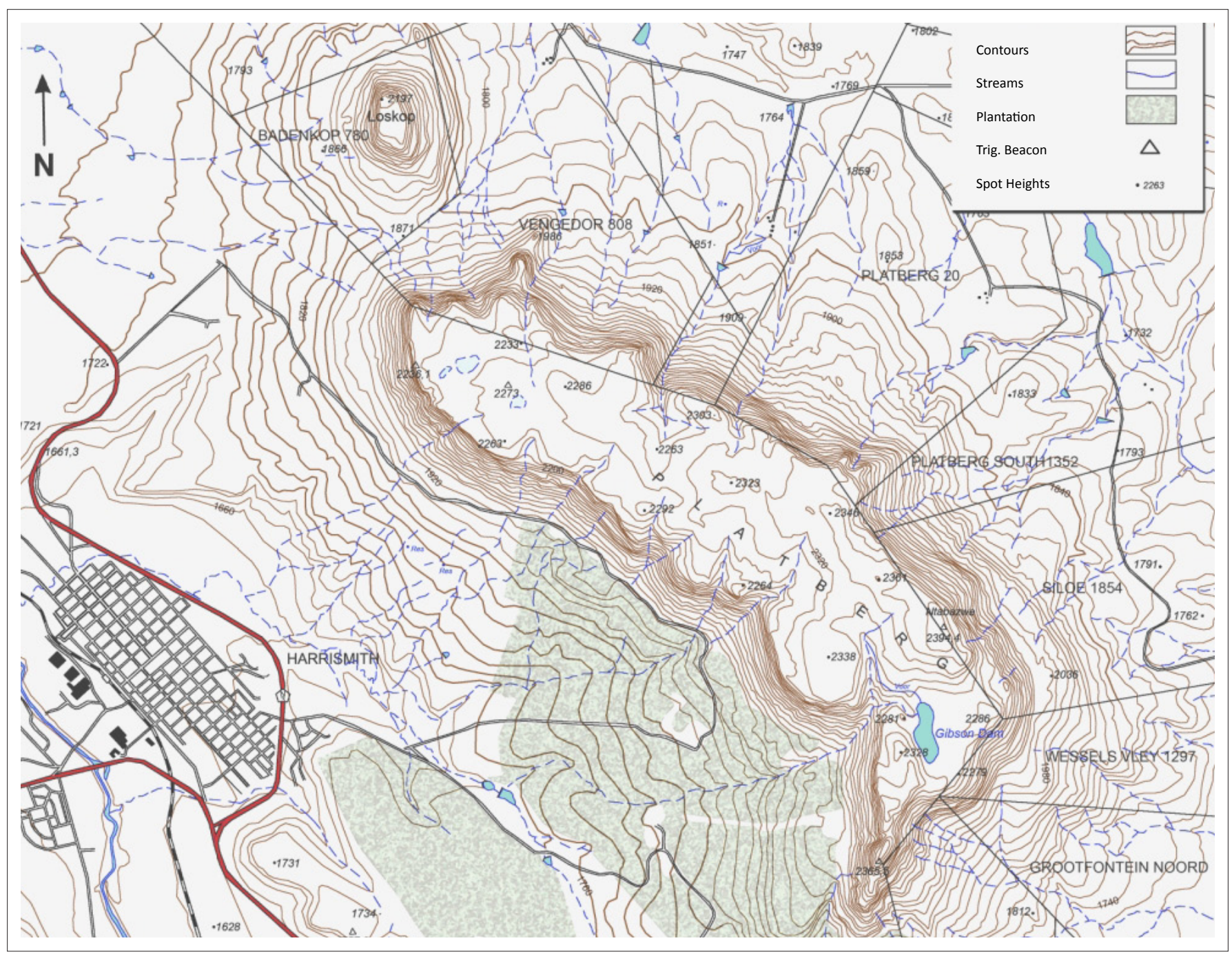

FIGURE 2: Topography of Platberg.

as listed below. The data set contains 6 trees, 62 shrubs, 55 grasses, 23 succulents, 19 sedges, 85 geophytes, 16 ferns, and 310 forb plant species. A total of 26 Drakensberg Alpine Centre (DAC) endemics and 22 alien plant species were found to be present (Brand, Du Preez \& Brown 2010). The variants are discussed in detail in Brand (2007) and are only listed in this paper. All phytosociological descriptions in this paper refer to the table provided the online supplement mentioned earlier.

1. Themeda triandra - Cyanotis speciosa major community

1.1 Cheilanthes eckloniana-Crassula sarcocaulis community

1.2 Hyparrhenia hirta - Tristachya leucothrix community 1.2.1 Hyparrhenia hirta - Leonotis ocymifolia subcommunity

1.2.2 Selago galpinii - Hyparrhenia hirta subcommunity

1.2.3 Felicia filifolia - Diospyros austro-africana subcommunity

1.2.4 Hyparrhenia hirta - Polygala hottentotta subcommunity

1.3 Eragrostis caesia - Ipomoea crassipes community 1.4 Cyanotis speciosa - Leonotis ocymifolia community
2. Agapanthus campanulatus - Aristida monticola major community

2.1 Andropogon appendiculatus - Helictotrichon longifolium community

2.1.1 Cineraria eriodioides - Senecio inornatus subcommunity

2.1.1.1 Senecio inornatus variant

2.1.1.2 Ficinia stolonifera variant

2.1.2 Tristachya leucothrix - Koeleria capensis subcommunity

2.1.3 Andropogon appendiculatus -Pennisetum sphacelatum subcommunity

2.1.3.1 Nemesia caerulea variant

2.1.3.2 Tristachya leucothrix variant

2.1.4 Watsonia lepida-Helichrysum pallidum subcommunity

2.1.5 Ledebouria cooperi - Selago galpinii subcommunity

2.1.6 Andropogon appendiculatus -Senecio paucicalyculatus subcommunity

2.1.7 Lotononis lotononoides - Hesperantha baurii subcommunity

2.1.7.1 Aster bakeranus variant

2.1.7.2 Erica alopecurus variant

2.1.8 Habenaria lithophyla - Eragrostis racemosa subcommunity 
2.2 Muraltia saxicola - Helichrysum chionosphaerum community

2.2.1 Muraltia saxicola - Aristea woodii subcommunity

2.2.2 Muraltia saxicola - Helichrysum aureum subcommunity

2.2.3 Ficinia stolonifera - Muraltia saxicola subcommunity

2.3 Andropogon distachyos - Helichrysum aureum community

2.4 Passerina montana - Melinis nerviglumis community

2.5 Cyperus semitrifidus - Digitaria monodactyla community

2.5.1 Digitaria monodactyla - Selaginella caffrorum subcommunity

2.5.2 Eriospermum ornithogalum - Digitaria monodactyla subcommunity

2.5.3 Digitaria monodactyla - Crassula sarcocaulis subcommunity

The grassland vegetation is characterised by the presence of the perennial bunch grasses Themeda triandra, Heteropogon contortus and Eragrostis curvula and the forbs Commelina africana and Oxalis obliquifolia (species group AM), with constancies higher than 50\% throughout the study area. Other prominent species include the short perennial grasses Tristachya leucothrix (species group AD), Eragrostis racemosa and Harpochloa falx, and the geophyte Watsonia lepida (species group AK).

\section{Themeda triandra - Cyanotis speciosa major community}

This major community is found on the hot, dry northern and western aspects of Platberg, at relatively low altitudes (1939 m.a.s.l. - 2078 m.a.s.l.).

This community is characterised by the presence of species from species group I (online supplement) and is dominated by the grasses Eragrostis curvula and Themeda triandra (species group AM). Other prominent species include the grass Tristachya leucothrix (species group AD) and the forb Cyanotis speciosa (species group I).

\subsection{Cheilantes ecklonia - Crassula sarcocaulis community}

This community is found on a north-western aspect on very steep slopes $\left(>26^{\circ}\right)$ in full sun at an altitude of approximately 2000 m.a.s.l. Rock cover varies from 5\% to 50\% with moist, shallow soils (20 mm - $180 \mathrm{~mm}$ deep). The geology is sheet rock outcrops on Clarens Formation sandstone and dolerite dykes. The community shows either no or moderate levels of trampling or erosion.

The community is characterised by species from species group A and includes the succulents Crassula sarcocaulis and Crassula lanceolata ssp. transvaalensis, the sedge Pycreus nigricans, the forb Pelargonium bowkerii and the geophytes Hypoxis filiformis and Ornithogalum tenuifolium. The community is poorly represented by species from other groups with a paucity of grasses. It has one dominant species - the xerophytic fern Cheilanthes eckloniana (species group
H) - and significant cover abundance from the grass dwarf succulent shrub $C$. sarcocaulis and the sedge $P$. nigricans (species group A), the grass Melinis nerviglumis (species group $\mathrm{H})$, the forb Bidens pilosa (species group I) and the geophyte Hypoxis costata (species group Y). The endemic geophyte Merwilla plumbea (species group AD) is also present. There is an average of 20.6 species per $30 \mathrm{~m}^{2}$.

\subsection{Hyparrhenia hirta - Tristachya leucothrix community}

This community is located at relatively low altitudes (1926 m - $2078 \mathrm{~m})$ on the warm northern or north-western aspect in full sun. The slope varies from moderate to very steep $\left(8^{\circ}-45^{\circ}\right)$. Rock cover varies from $0 \%$ to $40 \%$, with an average of between $5 \%$ and $10 \%$.

It is characterised by species from species group E and consists of only two grasses, namely Hyparrhenia hirta and Brachiaria serrata. The vegetation is dominated by the perennial grasses Tristachya leucothrix (species group AD) and Themeda triandra (species group AM), with significant cover abundance of Heteropogon contortus, Eragrostis curvula (species group AM), Eragrostis racemosa and Harpochloa falx (species group AL), the forb Felicia filifolia (species group AJ), the dwarf shrub Searsia discolor (species group AD), and the fynbos sub-shrub Selago galpinii (species group AD). The community has 32.41 species per $30 \mathrm{~m}^{2}$.

The Hyparrhenia hirta - Tristachya leucothrix community has four sub-communities:

\subsubsection{Hyparrhenia hirta - Leonotis ocymifolia subcommunity}

This subcommunity is located on the warm, dry northern side of Platberg on very steep $\left(26^{\circ}-45^{\circ}\right)$ slopes. Soils are dry and shallow $(30 \mathrm{~mm}-120 \mathrm{~mm})$, with little rock cover $(<10 \%)$. Moderate to high levels of trampling and erosion observed are due to vegetation use by cattle.

This subcommunity is characterised by the forbs Leonotis ocymifolia and the geophyte Asparagus cooperi from species group B. It is dominated by the perennial grasses Hyparrhenia hirta (species group E), Themeda triandra and Eragrostis curvula (species group AM), and Harpochloa falx (species group AL).

\subsubsection{Selago galpinii - Hyparrhenia hirta subcommunity}

This subcommunity is located on the northern moderate to steep $\left(8^{\circ}-26^{\circ}\right)$ stony hill slopes on the sandstone of the Clarens Formation. Soils are shallow $(40 \mathrm{~mm}-100 \mathrm{~mm})$ and dry and display moderate to high levels of trampling and erosion. Low sclerophyllous shrubs $(<2 \mathrm{~m})$ provide limited canopy cover $(<25 \%)$.

There is no diagnostic species group for this subcommunity and it is defined by the bunch grass Hyparrhenia hirta (species group E) and the sub-shrub Selago galpinii (species group AD). It is dominated locally by the perennial grasses Tristachya leucothrix (species group AD), Themeda triandra and Heteropogon contortus (species group AM). Other species that 
provide significant cover abundance include Felicia filifolia (species group AJ) and the forb Acalypha punctata (species group AD).

\subsubsection{Felicia filifolia - Diospyros austro-africana subcommunity}

The Felicia filifolia - Diospyros austro-africana subcommunity is located at an altitude of $2000 \mathrm{~m}$ on the hot, dry northern aspect. The slope is between $16^{\circ}$ and $45^{\circ}$. The subcommunity is located on Cave Sandstone sheet rock, with dry shallow soil (40 mm - $100 \mathrm{~mm}$ deep). No trampling or erosion was recorded. Canopy cover of between $5 \%$ and $15 \%$ was observed, provided by the low $(<2 \mathrm{~m})$ shrub Diospyros austro-africana.

Species group $\mathrm{C}$ defines this subcommunity and includes the shrubs D. austro-africana, Euclea crispa, Osyris lanceolata and Searsia dentata, the grass Trachypogon spicatus, the forb Helichrysum aureonitens and the fynbos shrub Cliffortia ramosissima.

The subcommunity is dominated by the perennial grasses Themda triandra, Eragrostis curvula (species group AM) and Eragrostis racemosa (species group AL), the low sedge Cyperus semitrifidus (species group AJ), and the dwarf shrub D. austro-africana (species group C). Other species locally dominant include the fynbos shrub C. ramosissima, the tree $E$. crispa (species group C) and the short grass Brachiaria serrata (species group E).

\subsubsection{Hyparrhenia hirta - Polygala hottentotta subcommunity}

The subcommunity is located between 1992 m.a.s.l. and 2078 m.a.s.l. on the hot, dry northern or north-eastern aspect. The slope varies from moderate to very steep $\left(16^{\circ}-45^{\circ}\right)$. Rock size varies from stones to boulders $(50 \mathrm{~mm}$ to more than $500 \mathrm{~mm}$ ). Soils are dry, mixed Ib type and of medium depth $(120 \mathrm{~mm}-200 \mathrm{~mm})$ on Cave Sandstone. Levels of erosion and trampling are moderate to high. Only one relevé had canopy cover (5\%) for shrubs lower than $2 \mathrm{~m}$. The vegetation comprises mostly tall, perennial grasses, with the shrub Diospyros austro-africana present in some areas.

Two plants from species group D define this community. They are the erect forb Polygala hottentotta and the uncommon succulent Aloe maculata. There is a well-developed grass layer that dominates the community and includes the perennial grasses Hyparrhenia hirta (species group E), Tristachya leucothrix (species group AD), Eragrostis racemosa (species group AL), Themeda triandra and Heteropogon contortus (species group AM). Other species of significance are the geophyte Hypoxis rigidula (species group F) and the grasses Cymbopogon dieterlenii (species group $\mathrm{AJ}$ ) and Eragrostis curvula (species group AM).

\subsection{Eragrostis caesia - Ipomoea crassipes community}

This community is found on the farm Platberg on most aspects on the northern flank of Platberg. The slope is steep to very steep $\left(16^{\circ}-45^{\circ}\right)$ on scree or boulder beds, below the
Cave Sandstone at an altitude of approximately 2000 m.a.s.l. Rock size exceeds $500 \mathrm{~mm}$, with exposure between $10 \%$ and $30 \%$. Soils are dry and shallow $(30 \mathrm{~mm}-120 \mathrm{~mm})$ and of mixed $\mathrm{Ib}$ type. No or only moderate trampling and erosion were observed.

This community is poorly developed and is characterised by the single grass species Eragrostis caesia (species group D). The community has no dominant species, but the grasses Themeda triandra, Eragrostis curvula, Heteropogon contortus (species group AM) and Tristachya leucothrix (species group AD) provide significant cover abundance. An average of 27.57 species per $30 \mathrm{~m}^{2}$ was recorded.

\subsection{Cyanotis speciosa-Leonotis ocymifolia community}

This community is located on basalt scree and boulder rubble on and below Cave Sandstone outcrops at altitudes between 2000 m.a.s.l. and 2100 m.a.s.l. It is located on the farm Platberg on the hot, dry northern or north-western grassy slopes $\left(16^{\circ}-45^{\circ}\right)$. Soils are shallow $(40 \mathrm{~mm}-120 \mathrm{~mm})$ with good drainage and not more than $15 \%$ rock cover. No or only moderate erosion and trampling due to livestock usage were observed.

This community has no single defining species group; it is characterised by the forbs Leonotis ocymifolia (species group B) and Cyanotis speciosa (species group I). Vegetativley it is poorly developed and dominated by a single grass, Themeda triandra, with significant presence of the perennial grasses Eragrostis curvula (species group AM), Harpochloa falx (species group AL) and Tristachya leucothrix, the dwarf shrub Searsia discolor and the forb Acalypha punctata (species group AD). An average of 24.88 species per $30 \mathrm{~m}^{2}$ was recorded.

\section{Agapanthus campanulatus - Aristida monticola major community}

This Grassland community is found on all aspects on the summit area of Platberg. It consists of relatively flat terrain on the plateau region or rocky outcrops on the summit or steep sides.

This major community is characterised by species group AI (online supplement) and is dominated by the forb Watsonia lepida (species group $\mathrm{AK}$ ) and short, perennial grasses Tristachya leucothrix (species group AD), Heteropogon contortus, Themeda triandra (species group AM), Eragrostis racemosa and Harpochloa falx (species group AL).

Within this major grassland community, two distinct vegetation divisions occur: a moist zone with deep soils, dominated by the tall maroon grass Andropogon appendiculatus (species group S), and a series of progressively rocky regions with shallow, dry soils dominated by three short grasses, namely T. leucothrix (species group AD), Elionurus muticus and Digitaria monodactyla (species group AJ).

\subsection{Andropogon appendiculatus - Helictotrichon longifolium community}

This community is located on all aspects of the summit area on flat or gently rolling terrain with damp soils $(>300 \mathrm{~mm}$ 
deep). No trampling or erosion is evident. There are no rock sheets, outcrops or boulders; the soil is fine grained $(<5 \mathrm{~mm})$. Species group $\mathrm{S}$ defines this community and includes the perennial bunch grasses Andropogon appendiculatus and Helictotrichon longifolium, the forbs Senecio inornatus and Zaluzianskya microsiphon. Vegetation is dominated by a welldeveloped grass layer, which includes $A$. appendiculatus, $H$. longifolium (species group S), Tristachya leucothrix (species group AD), Themeda triandra and Heteropogon contortus (species group AM), and the bulb Watsonia lepida (species group $\mathrm{AK}$ ). Other important species include the grasses Eragrostis racemosa, Harpochloa falx (species group AL) and the forb Helichrysum pilosellum (species group AB). This community has an average of 31.67 species per relevé.

This community has eight sub-communities and six variants.

\subsubsection{Cineraria eriodioides-Senecio inornatus subcommunity}

The Cineraria eriodioides - Senecio inornatus subcommunity has two variants. It is located on steep to very steep grassy slopes on the cool southern or south-western side of Platberg. Soils are gravelly mixed $\mathrm{Ib}$ type, with a depth of more than $300 \mathrm{~mm}$, and are damp or waterlogged. Rock exposure is either absent or between $5 \%$ and $20 \%$, with no trampling or erosion present. There are two distinct altitudes where the two variants occur; the Senecio inornatus variant at 2144 m.a.s.l. - 2297 m.a.s.l. and the Ficinia stolonifera variant lower down at 1950 m.a.s.l. - 2196 m.a.s.l.

The species Clutia affinis, Asparagus microraphis, Cineraria erodioides, Bupleurum mundii and the shrub Euclea coriacea (species group L) define the community.

Grasses, forbs, succulents and herbs are all poorly developed. The subcommunity is dominated by only two species: the forb S. inornatus (species group S) and the grass Themeda triandra (species group AM). Other species of importance include the perennial grasses Andropogon appendiculatus, Helictotrichon longifolium (species group S), Cymbopogon dieterlenii and Eragrostis chloromelas (species group AJ), the forb C. affinis (species group L) and the geophyte Watsonia lepida (species group AK).

\subsubsection{Tristachya leucothrix - Koeleria capensis subcommunity}

This subcommunity variant is located on the hot and dry western, south-western and north-eastern moderately sloping $\left(3^{\circ}-26^{\circ}\right)$ footslopes of Platberg at altitudes of between 1950 m.a.s.l. and 2100 m.a.s.l. Soils are shallow to deep ( $40 \mathrm{~mm}-300 \mathrm{~mm}$ ) and well drained, with rock exposure ranging between $0 \%$ and $20 \%$. The subcommunity is found on basalt scree rubble below the Cave Sandstone. No erosion or trampling is evident; however, the grasses are moribund.

There is an interesting community association of defining species, which includes the short, high-altitude grass Koeleria capensis, the sedge Cyperus obtusiflorus var. flavissimus and the Thymelaeaceae shrub Struthiola angustiloba. This shrub species usually occurs in an area between the Eastern Cape and southern KwaZulu-Natal and hence it is the first record of the species in the Free State. The community also includes two low Fabaceae shrubs, namely Argyrolobium harveyanum and Eriosema kraussianum (species group M).

The dominant species of the community form an extremely well-developed herbaceous layer and include the highaltitude, sour short grasses $K$. capensis (species group M), Tristachya leucothrix (species group AD), Elionurus muticus (species group AJ), Eragrostis racemosa, Harpochloa falx (species group AL) and Heteropogon contortus (species group AM).

Another species of significance is the perennial grass Andropogon appendiculatus (species group S). Herbs, forbs and geophytes are poorly developed, with the exception of Helichrysum pilosellum (species group AB).

\subsubsection{Andropogon appendiculatus - Pennisetum sphacelatum subcommunity}

The Andropogon appendiculatus - Pennisetum sphacelatum subcommunity is located on all aspects of Platberg, except for the hot, dry northern and north-western sides, on the moderately flat $\left(3^{\circ}-16^{\circ}\right)$ summit plateau area and on the steep to very steep $\left(16^{\circ}-45^{\circ}\right)$ midslope. The geology is either summit basalt or mixed Cave Sandstone and basalt scree slopes. Soils are all moist or waterlogged and generally deep (> $300 \mathrm{~mm}$ ), although shallow $(40 \mathrm{~mm}-120 \mathrm{~mm})$ soil is present on the midslope. Rockiness is either absent or between $5 \%$ and $25 \%$. This well-developed, tall $(600 \mathrm{~mm}-$ $1200 \mathrm{~mm}$ ) vegetation with its moist grassland community is moribund, indicating the lack of fire or grazing. It has two variants.

The Andropogon appendiculatus - Pennisetum sphacelatum subcommunity is characterised by species group $\mathrm{N}$ and is poorly represented by species other than the perennial grass Pennisetum sphacelatum. Other species include the tall forbs Senecio isatideus and Cynoglossum hispidum, the geophyte Moraea alticola and the prostrate herbs Trifolium burchellianum, Silene bellidioides and Silene undulata.

A well-developed grass layer dominates this community and includes P. sphacelatum (species group N), Andropogon appendiculatus (species group S), Tristachya leucothrix (species group AD), Aristida monticola (species group AI), Themeda triandra and Heteropogon contortus (species group AM), and the bulb Watsonia lepida (species group AK).

Other species common throughout this subcommunity include the grasses Helictotrichon longifolium (species group S) and Eragrostis curvula (species group AM), and the forbs Senecio inornatus (species group S) and Helichrysum pilosellum (species group $\mathrm{AB}$ ).

There are two variants, namely Nemesia caerulea and $T$. leucothrix.

\subsubsection{Watsonia lepida - Helichrysum pallidum subcommunity}

This subcommunity is located on all cool aspects of Platberg, at midslope altitudes of 1920 m.a.s.l. - 2100 m.a.s.l. and just 
below the summit plateau at $2248 \mathrm{~m}-2295 \mathrm{~m}$. The geology varies: the summit is pure basalt, whilst at lower altitudes there is a mix of Clarens Formation Sandstone, dolerite dykes and basalt scree. Soils are deep (> $300 \mathrm{~mm}$ ) and seasonally damp, with only four communities having rock exposure of between $5 \%$ and $15 \%$. No erosion or trampling was evident. The Watsonia lepida - Helichrysum pallidum subcommunity is a short-to-medium height $(300 \mathrm{~mm}-500 \mathrm{~mm})$ community with moribund grasses.

There is no single defining species group, with the community being characterised by the bulb Watsonia lepida (species group $\mathrm{AK}$ ) and the forb Helichrysum pallidum (species group $\mathrm{AB}$ ). Dominating the subcommunity are the grasses Tristachya leucothrix (species group AD) and Themeda triandra (species group AM), and W. lepida (species group AK). Species of importance include the grasses Andropogon appendiculatus, Aristida monticola (species group AI) and Heteropogon contortus, and the forbs Senecio inornatus (species group S) and Commelina africana (species group AM).

\subsubsection{Ledebouria cooperi - Selago galpinii subcommunity}

The Ledebouria cooperi - Selago galpinii subcommunity is found on moderate rolling slopes $\left(3^{\circ}-16^{\circ}\right)$ of the summit plateau. This subcommunity is a high-altitude one, found at 2282 m.a.s.l. - 2336 m.a.s.l., with seasonally moist soils that are generally more than $300 \mathrm{~mm}$ deep. However, some sample plots have shallow soils $(40 \mathrm{~mm}-120 \mathrm{~mm})$ with rock outcroppings of either $0 \%$ or between $5 \%$ and $15 \%$. Geology is summit basalt and shows no evidence of trampling or erosion.

The geophyte Ledebouria cooperi (species group AJ) and the small shrub Selago galpinii (species group AD) define this subcommunity. The subcommunity has a well-developed grass layer and is dominated by a single species, the perennial grass Tristachya leucothrix (species group AD). Other common species include the perennial grasses Andropogon appendiculatus (species group S), Aristida monticola (species group AI), Eragrostis racemosa, Harpochloa falx, Themeda triandra and Heteropogon contortus (species group AM), the sedge Carex zuluensis (species group AG) and the geophyte Watsonia lepida (species group AK).

\subsubsection{Andropogon appendiculatus - Senecio pauciculatus subcommunity}

The Andropogon appendiculatus - Senecio pauciculatus subcommunity is found on cool southern aspects of the plateau at 2307 m.a.s.l. - 2337 m.a.s.l. The terrain has a moderate slope $\left(3^{\circ}-16^{\circ}\right)$ with seasonally damp soils of medium depth $(80 \mathrm{~mm}-180 \mathrm{~mm})$ on basalt or Cave Sandstone. The subcommunity is located on rocky terrain with $5 \%-25 \%$ outcrop cover. There is no trampling or erosion.

This subcommunity has no single defining species. It is characterised by Andropogon appendiculatus (species group S) and Senecio pauciculatus (species group X). The community has a well-developed grass layer, which includes the perennial grasses A. appendiculatus, Helictotrichon longifolium (species group S) and Tristachya leucothrix (species group AD), the sour mountain grass Aristida monticola (species group AI), Elionurus muticus (species group AJ), the short sour grasses Eragrostis racemosa (species group AL), Heteropogon contortus and Themeda triandra (species group AM), the grass-like Dianthus mooiensis (species group $\mathrm{AB}$ ) and the geophyte Watsonia lepida (species group AK).

\subsubsection{Lotononis lotononoides - Hesperantha baurii subcommunity}

This Lotononis lotononoides - Hesperantha baurii subcommunity is a low-grass ( $300 \mathrm{~mm}-400 \mathrm{~mm})$, sub-shrub community located on all aspects of the cool, southern side of Platberg. Altitudes vary from 2198 m.a.s.l. to 2324 m.a.s.l. Geology is summit basalt or Cave Sandstone at slightly lower altitudes. The slope is either gently rolling $\left(3^{\circ}-8^{\circ}\right)$ or mild to steep $\left(16^{\circ}-45^{\circ}\right)$. Soils are seasonally damp and of medium depth $(100 \mathrm{~mm}-200 \mathrm{~mm})$ with some rock exposure $(5 \%-15 \%)$. No or moderate erosion was observed but no trampling was evident.

The Lotononis lotononoides - Hesperantha baurii subcommunity is characterised by members of species group $Q$ and includes the invasive alien tree Pinus patula, the geophyte Hesperantha baurii, the herbs Haplocarpha scaposa and Alepidea natalensis, the succulent Crassula vaginata and the grass Panicum coloratum.

The subcommunity is dominated by only two species, namely the sour grass Tristachya leucothrix (species group $\mathrm{AD}$ ) and the geophyte Watsonia lepida (species group AM). Other species with significant presence include the perennial grass Heteropogon contortus (species group AM) and the forb Lotononis lotononoides (species group AA).

There are two variants, namely Aster bakeranus and Erica alopecurus. Detailed descriptions of all variants, including these two, can be found in Brand (2007).

\subsubsection{Habenaria lithophyla - Eragrostis racemosa subcommunity}

This subcommunity is located on moderate to steep slopes $\left(8^{\circ}-26^{\circ}\right)$ on southern aspects of the stony summit basalt plateau area. Altitudes are high and range from 2254 m.a.s.l. to 2321 m.a.s.l. Rock exposure varies between $10 \%$ and $40 \%$ on very shallow, seasonally wet soils of $20 \mathrm{~mm}$ to $120 \mathrm{~mm}$ deep. No erosion or trampling is evident.

The small, erect orchid Habenaria lithophyla (species group $\mathrm{R}$ ) and the short grass Eragrostis racemosa (species group AL) define the subcommunity. It has poorly developed grammanoid geophytes and forbs. Species with significant presence include the grasses Tristachya leucotrix (species group $\mathrm{AD}$ ), Eragrostis racemosa (species group $\mathrm{AL}$ ) and Heteropogon contortus (species group AM), and the geophyte Watsonia lepida (species group AK).

\subsection{Muraltia saxicola - Helichrysum chionosphaerum community}

This community has three sub-communities and is located either on the summit basalt or the Cave Sandstone. This 
community occurs at either lower altitudes, at about $2100 \mathrm{~m}$, or high altitudes on stony, rocky summit areas between 2250 m.a.s.l. - 2378 m.a.s.l. Outcrop exposure varies from $5 \%$ to $25 \%$ along moderate slopes $\left(3^{\circ}-16^{\circ}\right)$. Soils are dry and shallow $(60 \mathrm{~mm}-180 \mathrm{~mm}$ ) or seasonally damp (180 mm - $220 \mathrm{~mm}$ deep). Vegetation varies between $200 \mathrm{~mm}$ and $400 \mathrm{~mm}$ high and shows little or no signs of erosion or trampling.

The succulent Delosperma sutherlandii, the two Asteraceous forbs Helichrysum chionosphaerum and Helichrysum argentissimum, and Xysmalobium involucratum from species group V define this community.

This community has a well-developed grass layer, which includes the perennial grasses Tristachya leucothrix (species group AD), Eragrostis racemosa, Harpochloa falx (species group AL) and Heteropogon contortus (species group AM), and the dominant geophyte Watsonia lepida (species group $\mathrm{AK}$ ). Other species of significance include the prostrate fynbos dwarf shrub Muraltia saxicola (species group W), the sedge Ficinia stolonifera (species group AI) and the forb $H$. chionosphaerum (species group V).

This community has an average of 34.41 species per relevé.

\subsubsection{Muraltia saxicola - Aristea woodii subcommunity}

This is a short-grass, prostrate forb community, located on stony, gradually sloping $\left(3^{\circ}-16^{\circ}\right)$ basalt terrain on the warm, northern aspects of Platberg. Soils are dry and shallow $(60 \mathrm{~mm}-180 \mathrm{~mm})$ on rocky outcrops showing 5\% - 20\% exposure. No trampling or erosion was recorded.

Species group $\mathrm{T}$ defines this community and includes the geophyte Aristea woodii, the forb Senecio inequidens and the orchid Satyrium longicaula.

The subcommunity is dominated by the short perennial grasses Tristachya leucothrix (species group AD), Eragrostis racemosa, Harpochloa falx (species group AL) and Heteropogon contortus (species group AM), and the bulb Watsonia lepida (species group AK).

\subsubsection{Muraltia saxicola-Helichrysum aureum subcommunity}

This prostrate sclerophyllerous forb subcommunity of medium height $(400 \mathrm{~mm})$ is located on all southern aspects on grassed, rocky basalt outcrops on the plateau area. It occurs at altitudes between 2250 m.a.s.l. and 2330 m.a.s.l., with $10 \%$ $-25 \%$ rock outcrop. Soils are seasonally damp, shallow to medium deep (40 mm - $220 \mathrm{~mm}$ ) and show no evidence of erosion or trampling.

The subcommunity is characterised by species from species group $\mathrm{U}$ and includes the forbs Helichrysum aureum and Wahlenbergia lycopodioides, the sedges Eleocharis dregeana and Scleria welwitschii, and the fynbos sub-shrub Gnidia fastigata. The short grasses Tristachya leucothrix (species group AD),
Eragrostis racemosa, Harpochloa falx (species group AL) and Heteropogon contortus (species group AM) and the geophyte Watsonia lepida (species group AK) dominate this subcommunity. There is limited presence of other species; the only ones of significance are the fynbos prostrate dwarf shrub Muraltia saxicola (species group W) and the forb Helichrysum chionosphaerum (species group V).

\subsubsection{Ficinia stolonifera - Muraltia saxicola subcommunity}

This sedge and prostrate sclerophyllous forb subcommunity is located on all aspects of Platberg on the summit basalt and the Cave Sandstone. Altitudes range from low (2100 m.a.s.1.) to high (2259 m.a.s.l. - 2378 m.a.s.l.). The slope is gradual $\left(3^{\circ}-8^{\circ}\right)$, with rock exposure of $10 \%-20 \%$ on seasonally damp soil of variable depths (between $20 \mathrm{~mm}$ and $200 \mathrm{~mm}$ ). Vegetation varies between $200 \mathrm{~mm}$ and $400 \mathrm{~mm}$ high and shows no signs of erosion or trampling.

There is no defining species group for this subcommunity, which is characterised by the common sedge Ficinia stolonifera (species group AI) and the prostrate fynbos sub-shrub Muraltia saxicola (species group W). It is dominated by a welldeveloped grammanoid layer, which includes the perennial grasses Tristachya leucotrix (species group AD), Eragrostis racemosa (species group AL) and Heteropogon contortus (species group AM), and the sedge Ficinia stolonifera (species group AI). The only forb and geophyte of significance are Helichrysum chionosphaerum (species group V) and Watsonia lepida (species group AK), respectively.

\subsection{Andropogon distachyos - Helichrysum aureum community}

The Andropogon distachyos - Helichrysum aureum community has a limited extent and is located on only three relevés. It comprises a total of 133 species. This community has the highest species average (43.33 species per relevé). It is found on rocky outcrops $(5 \%-15 \%$ exposure) on moderate to steep $\left(16^{\circ}-26^{\circ}\right)$ midslopes on the northern aspects between 1970 m.a.s.l. and 1993 m.a.s.l. The community is located on a dolerite dyke, which intrudes the Clarens Formation Cave Sandstone. The soil is a mixed Ib type. No or only moderate erosion and trampling are evident on well-drained soils that range from shallow to medium deep (40 mm - $200 \mathrm{~mm}$ ).

Members of species group $\mathrm{Z}$ define this community and include the the low fynbos sub-shrub Gnidia caffra, the perennial grasses Andropogon distachyos and Monocymbium ceresiiforme, the forbs Helichrysum aureum, Acalypha schinzii, Argyrolobium stipulaceum, Senecio coronatus, Xysmalobium parviflorus and Dicoma anomala, and the geophytic forb Pentanisia prunelloides.

There is a paucity of species from most other groups, with a poorly developed grass layer. Species that dominate this community include the perennial, short sour grasses $A$. distachyos (species group Z), Tristachya leucothrix (species group AD) and Eragrostis racemosa (species group AL), and the bulb Watsonia lepida (species group AK). Other important 
species include the grasses $M$. ceresiiforme (species group Z) and Themeda triandra (species group AM), and the forb $H$. aureum (species group Z).

\subsection{Passerina montana - Melinis nerviglumis community}

The Passerina montana - Melinis nerviglumis community comprises a mixture of woody and grass species with $5 \%$ $70 \%$ canopy cover provided by shrubs of between $2 \mathrm{~m}$ and $6 \mathrm{~m}$ high. It is located on the northern, north-western and southern aspects on mobile scree or the rocky $(15 \%-45 \%)$ contact between the basalt and Cave Sandstone on steep to very steep $\left(16^{\circ}-45^{\circ}\right)$ slopes. Soils are shallow to medium deep $(10 \mathrm{~mm}-200 \mathrm{~mm})$ and moderate to high erosion levels were recorded.

The Passerina montana - Melinis nerviglumis community is characterised by species from species group $\mathrm{AC}$, which comprises the low sclerophyllous shrub Passerina montana, the geophyte Ledebouria ovatifolia, the fern Asplenium aethiopicum, the caespitose forb Helichrysum sutherlandii, and the Restionaceae Ischyrolepis schoenoides.

It is dominated by only two species, namely the fynbos shrub P. montana (species group AC), and the bulb Watsonia. lepida (species group AK). It has a poorly developed grammanoid layer that includes Panicum ecklonii, Tristachya leucothrix (species group $\mathrm{AD}$ ), I. schoenoides (species group AC), the sedge Ficinia stolonifera (species group AI) and the grasses Themeda triandra, Heteropogon contortus and Eragrostis curvula (species group AM).

This community has an average of 35.40 species per relevé.

\subsection{Cyperus semitrifidus - Digitaria monodactyla community}

The Cyperus semitrifidus - Digitaria monodactyla community is located on all aspects and cardinal points on flat to moderate $\left(3^{\circ}-16^{\circ}\right)$ rocky terrain on the summit plateau basalt. Soils are shallow (20 mm - $120 \mathrm{~mm}$ ) and damp. Rock cover varies between $5 \%$ and $50 \%$, but averages $25 \%$. The vegetation is low $(10 \mathrm{~cm}-30 \mathrm{~cm})$, with poorly developed grass, forb, herb and succulent layers. The flat, wet, loose gravel and sheet rock nature of the community results in no or very little erosion and trampling.

There is no defining species group for this community; however, the sedge Cyperus semitrifidus and the short perennial grass Digitaria monodactyla, both from species group AJ, define this community. These two species also dominate the community, which has a poorly developed grass and forb layer. Additional species of importance include the mountain grass Aristida monticola and the two forbs Agapanthus campanulatus and Helichrysum dasycephalum (species group AI).

The Cyperus semitrifidus - Digitaria monodactyla community has three sub-communities, namely the Digitaria monodactyla - Selaginella caffrorum, Eriospermum ornithogaloides - Digitaria monodactyla and the Digitaria monodactyla-Crassula sarcocaulis sub-communities. The three sub-communities are defined by short grasses and prostrate ferns, minute geophytes, and karroid succulent shrubs, respectively.

The community is characterised by 14 relevés, with an average of 25.14 species per relevé.

\subsubsection{Digitaria monodactyla - Selaginella caffrorum subcommunity}

This is a low $(5 \mathrm{~cm}-25 \mathrm{~cm})$ subcommunity located on rock sheets with $25 \%-50 \%$ outcrop on basalt, dolerite and Cave Sandstone, on all aspects of Platberg. Soils are moist and very shallow $(20 \mathrm{~mm}-60 \mathrm{~mm})$, without any erosion or trampling.

Most grasses and forbs are poorly developed, with the community characterised by the single, fine-leaved prostrate fern Selaginella caffrorum (species group AE). Only two species dominate the community, namely the short grass Digitaria monodactyla (species group $\mathrm{AJ}$ ) and the fern S. caffrorum (species group AE). Other species of significance include the succulent sub-shrub Crassula sarcocaulis (species group A) and the geophyte Schizocarphus nervosa (species group AG).

\subsubsection{Eriospermum ornithogaloides-Digitaria monodactyla subcommunity}

This is subcommunity comprising low grasses $(100 \mathrm{~mm}-$ $200 \mathrm{~mm}$ ) and geophytes, located on the cool, southern side on flat basalt rock sheets with $10 \%-30 \%$ exposure on the summit plateau area. It occurs between 2196 m.a.s.l. and 2328 m.a.s.l. Soils are shallow $(20 \mathrm{~mm}-120 \mathrm{~mm})$, damp to seasonally waterlogged and consist of degraded gravel (grain $<10 \mathrm{~mm}$ ). No erosion or trampling is evident.

It has no defining species group; rather, it is characterised by the geophyte Eriospermum ornithogaloides (species group $\mathrm{AG}$ ) and the monotypic grass Digitaria monodactyla (species group AJ). It has a very poorly developed grass and forb layer, without any single species clearly dominating the subcommunity. Species of importance include the grass $D$. monodactyla and the forb Helichrysum dasycephalum (species group AJ) and the geophyte Agapanthus campanulatus (species group AI).

\subsubsection{Digitaria monodactyla - Crassula sarcocaulis subcommunity}

The Digitaria monodactyla-Crassula sarcocaulis subcommunity is found on rocky outcrops, gravel plains and rock sheets (exposure $5 \%-15 \%$ ) on the eastern aspect on all sides of the summit basalt at 2100 m.a.s.l. - 2350 m.a.s.l. Soils are shallow $(20 \mathrm{~mm}-100 \mathrm{~mm})$ and seasonally damp, without any erosion or trampling.

This subcommunity is characterised by succulent shrubs and low grasses, specifically Filipendula vulgaris and the small succulent Aloe aristata (species group AH). The herbaceous layer and species numbers are poorly developed throughout the community. The community is dominated by the succulent shrubs Crassula sarcocaulis (species group A) and Ruschia putterillii and the short sour grass Digitaria 
monodactyla, both from species group AJ. Other species of significance include two grasses, Cymbopogon dieterlenii and Eragrostis chloromelas, the sedge Cyperus semitrifudus (species group $\mathrm{AJ}$ ) and the exotic species F. vulgaris (species group $\mathrm{AH}$ ). The consistency of Cyanothis speciosa (species group I), which favours habitats with shallow soils on rocky terrain, should be noted.

\section{Species richness and structure}

Platberg has an average species richness of 30.98 species per $30 \mathrm{~m}^{2}$. The mean number of species (species abundance) in the two major communities are significantly different $(t(167)$ $=2.020, p<0.05$ ). The mean number of species is significantly higher in major community 2 than in major community 1 (31.7 vs. 28.3), with a $95 \%$ confidence interval for the difference between means $(0.08-6.85)$. The descriptive statistics for species abundance are provided in Table 1.

For major community 1 , the sample plots were located at relatively low altitudes $(<2000$ m.a.s.l.), with an average species richness of 28.27 species per $30 \mathrm{~m}^{2}$. For major community 2 , the relevés were spread over the plateau area of Platberg at altitudes higher than 2000 m.a.s.l., with an average species richness of 31.73 species per $30 \mathrm{~m}^{2}$. Thus, the data indicate that more species occur at higher altitudes.

Owing to a significant difference in species abundance between the major communities, the next step in the analysis process was to examine differences between the species abundance of the respective communities within each of the major communities. No significant difference was found for the species abundance of the communities comprising major community 1, with Kruskal-Wallis $H(3, N=37)=7.14$, $p>0.05$. A significant difference in species abundance was found between the communities within major community 2, with Kruskal-Wallis $H(4, N=132)=15.75, p<0.01$. Moreover, multiple comparisons of the mean ranks for all groups within major community 2 revealed significant differences between the species abundance of communities 2.2 and 2.5, and also between communities 2.3 and 2.5 ( $p<0.05$ for both comparisons). Figures 3 and 4 provide graphic representations of these comparisons in the form of box plots, with $95 \%$ confidence intervals for median values of the species abundance of the communities within major communities 1 and 2, respectively. (The descriptive statistics for species abundance for the communities within each of the major communities are provided in Table 2.) In both these comparisons, the species abundance of community 2.5 was the lower of the respective pairs. Community 2.5 occurs on shallow, moist soil that is underlain by basalt rock sheets. These conditions are not conducive to plant growth, which could explain the low species richness of this high-altitude community. Both communities 2.2 and 2.3 are located on rocky terrain with deeper soil and a combination of grasses, forbs and low shrubs. This higher species richness of rocky terrains may be ascribed to rocks protecting seedlings and young plants from grazing and fire, as well as to reduced effects of shading from tall woody vegetation (Everson, Everson \& Tainton 1988; Heini, Silva \& Tacheba 2004; Seabloom \& Richards 2003).

\section{Discussion}

With regard to species composition, the grassland communities along the slopes and footslopes (major community 1) and those on the plateau (major community 2) on Platberg show distinct dissimilarities. This can be attributed to different geological substrates, altitude differences and percentage surface rock. The Themeda triandra - Cyanotis speciosa major community (1) occurs on shallow soils mostly on the Clarens, Elliot and Molteno Formations and is composed, generally, of short grasses and low forbs on rocky terrain or outcrops. The Agapanthus campanulatus - Aristida monticola major community (2) is a medium-to-tall grassland restricted to the plateau (basalts and dolerite) with deeper soil and higher clay content, which has greater moisture retention ability.

\section{Floristic affinities}

Some floristic associations exist between Platberg and Korannaberg, which is located approximately $300 \mathrm{~km}$ west of Platberg in the drier interior of the eastern Free State.

TABLE 1: Species richness for the major plant communities on Platberg.

\begin{tabular}{lllll}
\hline Major community & \multicolumn{4}{c}{ Species statistics } \\
\cline { 2 - 5 } & Number of species & Mean & s.d. & Median \\
\hline 1 & 37 & 28.27 & 8.84 & 27 \\
2 & 132 & 31.73 & 9.32 & 31 \\
\hline Total & $\mathbf{1 6 9}$ & $\mathbf{3 0 . 9 8}$ & $\mathbf{9 . 3 0}$ & $\mathbf{3 1}$ \\
\hline
\end{tabular}

s.d., standard deviation

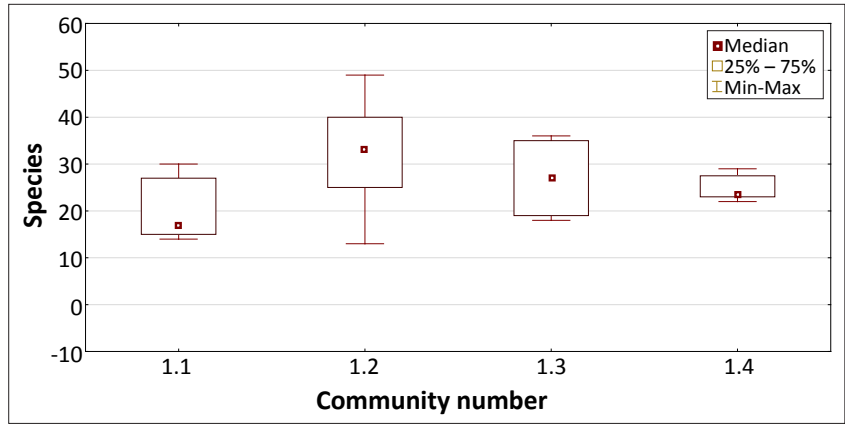

FIGURE 3: Species abundance of the communities within major community 1.

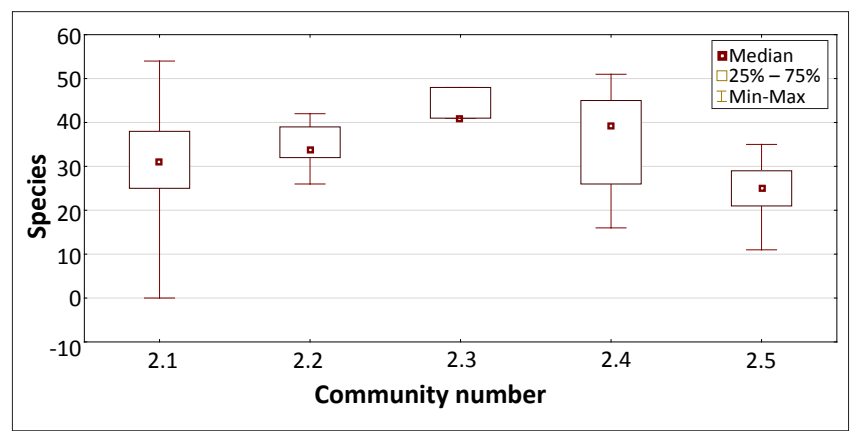

FIGURE 4: Species abundance of the communities within major community 2. 
TABLE 2: Species abundance for the different communities within each of the major communities.

\begin{tabular}{|c|c|c|c|c|c|}
\hline \multirow[t]{2}{*}{ Major community } & \multirow[t]{2}{*}{ Community number } & \multicolumn{4}{|c|}{ Species } \\
\hline & & $N$ & Means & s.d. & Median \\
\hline 1 & 1.1 & 5 & 20.60 & 7.37 & 17 \\
\hline 1 & 1.2 & 17 & 32.41 & 9.85 & 33 \\
\hline 1 & 1.3 & 7 & 27.57 & 7.23 & 27 \\
\hline 1 & 1.4 & 8 & 24.88 & 2.70 & 23.5 \\
\hline 2 & 2.1 & 93 & 31.67 & 9.55 & 31 \\
\hline 2 & 2.2 & 17 & 34.41 & 4.81 & 34 \\
\hline 2 & 2.3 & 3 & 43.33 & 4.04 & 41 \\
\hline 2 & 2.4 & 5 & 35.40 & 14.26 & 39 \\
\hline 2 & 2.5 & 14 & 25.14 & 6.60 & 25 \\
\hline Total group & & 169 & 30.98 & 9.30 & 31 \\
\hline
\end{tabular}

$N$, sample size; s.d., standard deviation.

Korannaberg is the only other inselberg on which a similar study has been conducted. It is at a lower altitude (1500 m - 1881 m) (Du Preez 1991; Du Preez \& Bredenkamp 1991) and has no basaltic cap. Common species shared by these two sites include the grasses Cymbopogon dieterlenii, Digitaria monodactyla, Elionurus muticus, Eragrostis capensis, Eragrostis chloromelas, Eragrostis curvula, Eragrostis racemosa, Harpochloa falx, Pentaschistis setifolia, Themeda triandra and Tristachya leucothrix, and the forbs Helichrysum nudifolium, Selaginella caffrorum and Crassula lanceolata.

The Festuca caprina grassland of the Golden Gate Highlands National Park and Qwa-Qwa National Park (Mucina \& Rutherford 2006) also has similarities with that of Platberg. Grasses prominent in both areas include C. dieterlenii, E. muticus, E. curvula, T. triandra and T. leucothrix. Floristic links also exist with the Cathedral Peak area of the Drakensberg, where the Themeda-Festuca sub-alpine sour grassland dominates the main montane region. These genera are also dominant on Platberg.

Numerous species recorded at Platberg and in the Drakensberg at a high altitude have been identified for primary grassland communities in Gauteng (Behr \& Bredenkamp 1988) and for the Bankenveld (Bredenkamp \& Brown 2003; Grobler, Bredenkamp \& Brown 2006). They include Ajuga ophrydis, Schistostephium crataegifolium, Senecio isatideus, Senecio inornatus, Sida dregei, the woody Gnidia capitata and Searsia discolor. Grasses, which are either characteristic or dominant species in Platberg and have also been recorded by Grobler et al. (2006) and Bredenkamp and Brown (2003), include Brachiaria serrata, D. monodactyla, E. muticus, E. racemosa, E. chloromelas, E. curvula, Heteropogon contortus, Hyparrhenia hirta, Melinis nerviglumis, Monocymbium ceresiiforme, Panicum natalensis, Setaria sphacelata, T. triandra, Trachypogon spicatus and T. leucothrix.

Species recorded at Platberg that emphasise the floristic relationships of the DAC, the Karoo and the Fynbos (Acocks 1988; Hill 1996; Hilliard \& Burtt 1987; Kay, Bredenkamp \& Theron 1993; Moffett et al. 2001; Roberts 1969) include: A. ophrydis, Andropogon appendiculatis, Aristida junciformis, Aristida monticola, B. serrata, Cheilanthes quadripinnata, Cheilanthes hirta, Commelina africana, Crassula alba, D. monodactyla, E. racemosa, E. chloromelas, E. curvula, E. muticus, Euclea crispa, Euphorbia striata, G. capitata, H. falx, Helichrysum aureonitens, Helichrysum polycladum, Helichrysum rugulosum, Helichrysum cephaloideum, Hermannia depressa, $H$. contortus, $H$. hirta, Ipomoea crassipes, Leucosidea sericea, M. nerviglumis, M. ceressiforme, Myrsine africana, Pollichia campestris, Searsia rigida, S. discolor, S. isatideus, Pennisetum sphacelatum, T. triandra, T. spicatus and Vernonia natalensis.

According to Mucina and Rutherford (2006) three major temperate grassland genera, namely Festuca, Bromus and Koeleria, represent a northern affinity, showing links with East Africa and Eurasia, whilst genera such as Pentaschistis and Merxmuellera have southern affinities with the Cape region. These genera are also present on Platberg, indicating floristic affinity with these areas.

\section{Conservation}

Very little of the DAC grassland is preserved, with the majority in KwaZulu-Natal and a smaller portion in the Golden Gate Highlands National Park and the Qwa-Qwa National Park (now incorporated into the Golden Gate Highlands National Park). Only 5.5\% $\left(2194 \mathrm{~km}^{2}\right)$ of the entire DAC is protected (Carbutt \& Edwards 2004, 2006). These habitats, with their complex abiotic and biotic factors, are responsible for generating high species richness (Cowling, Holmes \& Rebelo 1992; ed. Huntley 1989; Van Wyk \& Smith 2001).

The Platberg grasslands as found in this study are mostly natural with limited human impact and a relatively high species richness. Various affinities with other high-altitude grasslands exist and as such the conservation of this area will contribute to the conservation of the larger Grassland biome in southern Africa.

\section{Conclusion}

Prior to this study, very little was known about the vegetation of Platberg. This phytosociological classification and description of the vegetation of Platberg serves as an inventory of the natural ecosystems and plant species present in the area.

This study resulted in the identification 26 plant communities, which can be grouped into two major 
communities. A total of 551 vascular plants, of which 26 are endemic or near-endemic DAC species, were identified. Floristic affinities with various other high-lying grasslands were found.

The species richness of the study area, together with the threat of declining genetic diversity (ed. Anderson 2001), global warming and subsequent climate change (Peters 1992), underlines the importance of mountains and the associated inselbergs as refuge areas for different plant species and the need for their urgent protection.

As a unit the Grassland biome requires more protected areas, identified according to ecological criteria based on phytosociological studies that are able to identify vegetation units on which rare, threatened, endemic or near-endemic plants grow. It is important that Platberg specifically, but inselbergs generally, be given attention as conservation sites with the development of a management plan by the Department of Environment, Tourism and Economic Affairs of the Free State. The results of this study could serve as a basis for future conservation planning and management of the area.

The presence of various alien plant species poses a threat to the natural vegetation. It is recommended that an eradication plan is implemented as soon as possible so as to prevent the degradation of this natural grassland ecosystem.

\section{Acknowledgements}

The authors acknowledge the National Geographic Society (Grant number 7920-05) for the generous funds without which the fieldwork and the study would not have been possible.

\section{Authors' contributions}

R.F.B., L.R.B. and P.J.d.P. all contributed equally to data collection and analysis and subsequent writing of the manuscript.

\section{References}

Acocks, J.P.H., 1988, Veld types of South Africa, Botanical Research Institute, Pretoria. (Memoirs of the Botanical Survey of South Africa, no. 57)

Anderson, J.M. (ed.), 2001, Towards Gondwana Alive, National Botanical Institute Pretoria.

Behr, C.M. \& Bredenkamp, G.J., 1988, 'An analysis of the flowering plants and ferns of the Witwatersrand National Botanic Garden', South African Journal of Botany 54(6), 515-524.

Brand, R.F., 2007, 'Phytosociology of Platberg mountain, eastern Free State, South Africa', PhD thesis, Dept. of Plant Sciences, University of the Free State.

Brand, R.F., Du Preez, P.J. \& Brown, L.R., 2008, 'A floristic description of the Afromontane Fynbos communities on Platberg, Eastern Free State, South Africa', Koedoe 50(1), 202-213.

Brand, R.F., Du Preez, P.J. \& Brown, L.R., 2010, 'A floristic analysis of the vegetation of Platberg, Eastern Free State, South Africa', Koedoe 52(1), 1-11.

Bredenkamp, G.J. \& Brown, L.R., 2003, 'A reappraisal of Acocks' Bankenveld: Origin and diversity of vegetation types', South African Journal of Botany 69(1), 7-26.

Burke, A., 2001, 'Determinants of inselberg floras in arid Nama Karoo landscape', Journal of Biogeography 22, 1211-1220.

Burke, A., 2004, 'From plains to inselbergs: Species in special habitats as indicators of climate change?', Journal of Biogeography 31, 831-841. http://dx.doi. org/10.1046/j.1365-2699.2003.00984.x
Carbutt, C. \& Edwards, T.J., 2004, 'The flora of the Drakensberg Alpine Centre', Edinburgh Journal of Botany 60(3), 581-607.

Carbutt, C. \& Edwards, T.J., 2006, 'The endemic and near-endemic angiosperms of the Drakensberg Alpine Centre', South African Journal of Botany 72, 105-132.

Cowling, R.M., Holmes, P.M. \& Rebelo, A.G., 1992, 'Plant diversity and endemism', in R.M. Cowling (ed.), The ecology of fynbos: Nutrients, fire and diversity, pp. 4-21 Oxford University Press, Cape Town.

Du Preez, P.J., 1991, 'A syntaxonomical and synecological study of the vegetation of the south-eastern Orange Free State and related areas with special reference to Korannaberg', PhD thesis, Dept. of Plant Sciences, University of the Orange Free State.

Du Preez, P.J., 1992, 'The classification of the vegetation of Korannaberg, eastern Orange Free State, I, Afromontane fynbos communities', South African Journal of Botany 58(3), 165-172.

Du Preez, P.J. \& Bredenkamp, G.J., 1991, 'Vegetation classes of the southern and eastern Orange Free State (Republic of South Africa) and the highlands of Lesotho', Navorsing Nasionale Museum, Bloemfontein 7, 477-526.

Du Preez, P.J., Bredenkamp, G.J. \& Venter, H.J.T., 1991, 'The syntaxonomy and synecology of the forests in the eastern Orange Free State, South Africa', South African Journal of Botany 57, 198-206.

Everson, C.S., Everson, M.T. \& Tainton, N.M., 1988, 'Effects of intensity and height of shading on the tiller initiation of six grass species from the Highland sourveld of Natal', South African Journal of Botany 54(4), 315-318.

Germishuizen, G. \& Meyer, N.L. (eds.), 2003, Plants of southern Africa: an annotated checklist, National Botanical Institute, Pretoria (Strelitzia, no. 14).

Grobler, C.H., Bredenkamp, G.J. \& Brown, L.R., 2006, 'Primary grassland communities of the urban open spaces in Gauteng, South Africa', South African Journal of of the urban open spaces in Gauteng, South Africa', South African
Botany 72, 367-377. http://dx.doi.org/10.1016/j.sajb.2005.10.008

Heini, M., Silva, J. \& Tacheba, B., 2004, 'Vegetation changes after a single fire-event in the Okavango Delta wetland, Botswana', South African Journal of Botany 70(5), 695-704.

Hennekens, S.M., 1996a, TURBOVEG: A software package for input, processing and presentation of phytosociological data,computer software, University of and presentation of
Lancaster, IBN-DLO.

Hennekens, S.M., 1996b, MEGATAB: A visual editor for phytosociological tables, computer software, Giesen \& Geurts, Ulft.

Hennekens, S.M., 1998, TURBOVEG: Clipper database management software for storage, selection, and export of vegetation data (relevés), computer software, Green World Research, Wageningen.

Hill, T.R., 1996, 'Description, classification and ordination of the dominant vegetation communities, Cathedral Peak, KwaZulu-Natal Drakensberg', South African Journal of Botany 62, 263-269.

Hilliard, O.M. \& Burtt, B.L., 1987, The Botany of Southern Natal Drakensberg, National Botanical Gardens, Cape Town.

Hoare, D.B. \& Bredenkamp, G.J., 2001, 'Syntaxonomy and environmental gradients of the grasslands of the Stormberg/Drakensberg mountain region of the Eastern Cape, South Africa', South African Journal of Botany 67, 595-608.

Huntley, B.J. (ed.), 1989, Biotic Diversity in Southern Africa, Concepts and conservation Oxford University Press, Cape Town.

Huntley, B.J. (ed.), 1994, Botanical Diversity in Southern Africa, National Botanical Institute Press, Pretoria (Strelitzia, no. 1).

Johnson, M.R., Van Vuuren, C.J., Visser, J.N.J., Cole, D.I., Wickens, H. de V., Christie, A.D.M. et al., 2006, 'Sedimentary rocks of the Karoo Supergroup', in M.R. Johnson, C.R. Anhaeusser \& R.J. Thomas (eds.), The geology of South Africa, pp. 461-499, Geological Society of South Africa, Johannesburg.

Kay, C., Bredenkamp, G.J. \& Theron, G.K., 1993, 'The plant communities of the Golden Gate Highlands National Park in the north-eastern Orange Free State', South African Journal of Botany 59(4), 442-449.

Keddy, P.A., 2007, Plants and vegetation: Origins, processes and consequences, Cambridge University Press, Cambridge.

Kent, M. \& Coker, P., 1992, Vegetation description and analysis: A practical approach, John Wiley \& Sons, Chichester.

Killick, D.J.B., 1963, An account of the plant ecology of the Cathedral Peak area of the Natal Drakensberg, Government Printer, Pretoria (Memoirs of the Botanical Survey of South Africa, no. 34).

Killick, D.J.B., 1978, 'The Afro-alpine Region', in M.J.A. Werger (ed.), Biogeography and ecology of Southern Africa, pp. 515-560, Junk, The Hague.

Malan, P.W., 1998, 'Vegetation ecology of the Southern Free State', PhD thesis, Dept. of Plant Sciences, University of the Orange Free State.

Moffett, R.O., Daemane, M.E., Pitso, T.R., Lentsoane, R. \& Taoana, T.R.N., 2001, 'A checklist of the vascular plants of Qwa-Qwa and notes on the flora and vegetation of the area', UNIQWA Research Chronicles 3(2), 32-83.

Mucina, L. \& Rutherford, M.C., 2006, The vegetation of South Africa, Lesotho and Swaziland, South African National Biodiversity Institute, Pretoria. (Strelitzia, no 19)

Mueller-Dombois, D. \& Ellenberg, H., 1974, Aims and methods of vegetation ecology, John Wiley \& Sons, New York.

Parmentier, I., Oumorou, M., Porembski, S., Lejoly, J. \& Decocq, G., 2006, 'Ecology, distribution, and classification of xeric monocotyledonous mats on inselbergs in West Africa and Atlantic central Africa', Phytocoenology 36(4), 547-564. 
Peters, R.L., 1992, 'Conservation of biological diversity in the face of climatic change', in R.L. Peters \& T.E. Lovejoy (eds.), Global warming and biological diversity, pp. in R.L. Peters \& T.E. Lovejoy (eds.), Global
$15-30$, Yale University Press, New Haven.

Porembski, S. \& Barthlott, G.B., 1995, 'A species poor tropical sedge community: Afrotrilepis pilosa mats on inselbergs in West Africa', Nordic Journal of Botany 16(3), 239-246.

Porembski, S. \& Brown, G., 1995, 'The vegetation of inselbergs in the Comoé National Park (Ivory Coast)', Conservatoire et Jardin Botanicues de Geneve 50(2), 351-365.

Porembski, S., Martinelli, G., Ghlemüller, R. \& Barthlott, W., 1998, 'Diversity and ecology of saxicolous vegetation mats on inselbergs in the Brazilian Atlantic rainforest', Diversity and Distribution 4, 107-119.

Porembski, S., Szarzynske, J., Mund, J-P. \& Barthlott, W., 1996, 'Biodiversity and vegetation of small-size inselbergs in a West African rain forest (Taï, Ivory Coast)', Journal of Biogeography 23, 47-55.

Roberts, B.R., 1969, 'The vegetation of the Golden Gate Highlands National Park', Koedoe 12, 15-28.
Seabloom, E.W. \& Richards, S.A., 2003, 'Multiple stable equilibrium in grassland mediated by herbivore population dynamics and foraging behaviour', Ecology 84(11), 2891-2904. http://dx.doi.org/10.1890/02-0020

South African Weather Services, 2007, Climate of South Africa, climate statistics for Bethlehem from 1961-1990, Government Printers, Pretoria.

Soil Classification Working Group, 1991, Soil classification: A taxonomic system for South Africa, Department of Agricultural Development, Soil and Irrigation Research Institute, Pretoria. (Memoirs on the Agricultural Natural Resources of South Africa, no. 15)

STATISTICA version 9.0, 2009, computer software, StatSoft Inc., New York.

Van Wyk, A.E. \& Smith, G.F., 2001, Regions of floristic endemism in Southern Africa: $A$ review with emphasis on succulents, Umdaus Press, Pretoria.

Westhoff, V. \& Van der Maarel, E., 1980, 'The Braun-Blanquet approach', in R.H. Whittaker (ed.), Classification of plant communities, pp. 287-378, Kluwe Academic Publishers, The Hague. 